\title{
Małgorzata Cygańska
}

University of Warmia and Mazury in Olsztyn e-mail: m.cyganska@uwm.edu.pl

ORCID: 0000-0003-4548-2915

\section{A CLINICAL EFFICIENCY INDEX FOR THE MEASUREMENT OF HOSPITAL PERFORMANCE: DEVELOPMENT AND VALIDATION WSKAŹNIK SPRAWNOŚCI KLINICZNEJ DO POMIARU DOKONAŃ SZPITALA: ROZWÓJ I WALIDACJA}

DOI: $10.15611 / \mathrm{pn} .2019 .2 .14$

JEL Classification: B26, I15, M41, P17

Summary: Managers' requirements for modern hospital performance measurement systems emphasize the need for including in the analysis clinical data. A hospital's financial status cannot be fully and reliably evaluated without access to such data. The existing research concerning the hospital performance measurement systems using financial and non-financial data in the process of managing healthcare facilities is limited. Therefore the aim of the study was to develop a new measure - the clinical efficiency index - which can be used to evaluate the operational efficiency of a hospital based on both, costs and clinical factors. The study showed that conclusions drawn from financial analysis differs when covering clinical aspects. The main contribution of this work is to provide healthcare professionals with a more focused perspective towards incorporating clinical factors into the hospital performance measurement system.

Keywords: hospital, performance measurement system, efficiency index, financial data, non-financial data.

Streszczenie: Oczekiwania menedżerów dotyczące nowoczesnych systemów oceny dokonań szpitali obejmują uwzględnienie w nich danych klinicznych. Nie można w pełni i wiarygodnie ocenić sytuacji finansowej szpitala bez dostępu do takich danych. Dotychczasowe badania dotyczące systemów pomiaru i oceny dokonań szpitali - wykorzystujących dane finansowe i niefinansowe $\mathrm{w}$ procesie zarządzania placówkami opieki zdrowotnej - są ograniczone. Dlatego celem przeprowadzonych badań było opracowanie nowego miernika wskaźnika sprawności działań na oddziale, który to można wykorzystać do oceny wydajności operacyjnej szpitala na podstawie zarówno kosztów, jak i czynników klinicznych. Uwzględnienie aspektów klinicznych w systemie oceny dokonań szpitala pozwala na bardziej wyczerpujące wnioski oraz wskazuje na pożądane kierunki zmian szpitalnych systemów pomiaru dokonań.

Słowa kluczowe: szpital, system pomiaru dokonań, wskaźnik sprawności, dane finansowe, dane niefinansowe. 


\section{Introduction}

Hospitals occupy a special place in the healthcare system, not only because they generate substantial costs, but mainly because they provide essential services for the entire population. The security of national healthcare is determined by the effectiveness of primary care services in hospitals which require effective management and adequate evaluation tools to cope with limited resources and complex legal and economic regulations. The provision of healthcare services is the main and most important role of hospitals. The selected management methods and tools should guarantee safe and affordable hospital services of high quality. These aspects are influenced by economic and clinical decisions whose effectiveness can be evaluated. Many healthcare organizations have been developing key performance indicators for monitoring, measuring and managing the performance of their healthcare systems to ensure effectiveness, efficiency, equity and quality [Khalifa, Khalid 2015; Hass-Symotiuk (ed.) 2011]. From the financial and clinical perspective, the effectiveness of healthcare services should be measured and assessed to rationalize the usage of healthcare resources. Management efficiency is one of the key areas of a hospital's management system, and medical personnel should play a special role in that system. Healthcare managers are responsible for raising medical personnel's awareness that their decisions lead to resource depletion and generate costs [Ferguson, Lapsley 1989]. Healthcare managers are aware of the effect of using measures on monitoring and improving performance, yet they rarely use measurement as an essential part of their strategies and tactics [Khalifa, Khalid 2015]. Physicians should be provided with cost data to rationalize their resource use and be aware that the higher the cost of treating an individual patient, the fewer resources are left for the treatment of the remaining patients [Frazier et al. 1991; Cohen et al. 1982]. In this context, effective and rational resource use should satisfy the needs of physicians, the health insurance system and the patients. Due to limited resources and the need for rational resource use, the selection of effective management methods and performance measures plays a very important role in hospital operations.

Most of the work on assessing hospital performance has been limited to various indicators developed separately for finance, health outcomes, distribution, productivity, and patient satisfaction [Linna et al. 2006; Kludacz 2009; Chluska 2017]. Some of the authors emphasize efficiency to be one of the most important objectives of a healthcare system, others highlight that the main managerial challenge for hospital administrators is increasing efficiency through cost control [Ford et al. 1997; Sitzia, Wood 1997; Linna et al. 2006]. In a hospital performance measurement system, a special role is played by financial and clinical indicators as performance data [Hafner et al. 2011]. In modern hospital information systems, financial data (measurable and non-measurable) influences or can influence, hospital operations [Raulinajtys-Grzybek et al. 2017]. Cost and revenue data are special types of 
information. One of the greatest challenges in a performance measure system is the process of structuring financial and operating data in a manner that creates full access to information about the economic activities of an entity [Nita (ed.) 2010; Nowak (ed.) 2012]. The relevance of the data generated by performance measurement systems has limitations regarding its adequacy. This plays a parti-cularly important role in business management, therefore the role of management in a healthcare facility is to raise medical personnel's awareness that the resources required for the provision of medical services are limited [Jacobs et al. 2004]. Medical personnel do not have access to comprehensive information about the key cost-forming factors, which constitutes the main barrier to the implementation of modern management methods in hospitals. A hospital's financial status cannot be fully and reliably evaluated without access to such data. The existing research concerning the hospital performance measurement systems (HPMS) using financial and non-financial data in the process of managing healthcare facilities is limited. Therefore, the aim of the study is to develop a new measure - the clinical efficiency index (CEI) - which can be used to evaluate the operational efficiency of a hospital based on both, costs and clinical factors.

\section{Clinical efficiency index - conceptual framework}

Managers' requirements for modern hospital performance measurement systems emphasize the need for incorporating clinical data in HPMS. Clinical data should be an integral part of HPMS to guarantee that the generated information (real and predicted) is valuable for users, including the users who are responsible for healthcare in hospitals.

The proposed concept for developing CEI is based on an analysis of costforming factors applicable to cost outliers (CO) to explain the asymmetry of treatment costs and provide useful data for operational management [Cygańska 2018]. Factors that significantly increase the risk of outliers are identified by multivariate regression analysis. The resulting model indicates which of the parameters identified in the first stage of the analysis generate outlying costs. The cost-forming factors identified in regression analysis are used to build a CEI scale for a qualitative description of patient-related parameters: health condition on admission and hospital course. The developed scale illustrates the correlations between the patient profile, health condition on admission and hospital course vs. treatment costs. The scale is developed with the use of beta coefficients of the normalized parameters in multiple regression analysis. The above approach is applied to compare the significance of quantitative and qualitative parameters, including parameters recorded in different units of measurement. The number of clinical efficiency points (CEP) scored by every factor in each category is added up for every patient to produce a CEI which describes the cost intensity of treatment 
based on the identified cost-forming factors which characterize the patient, the patient's health condition, and the hospital course. The higher the CEI, the better the relation between the patient's health status and the hospital costs. The clinical efficiency index is described as follows.

$$
C E I=\frac{C E P}{I C}=\frac{\sum_{j=1}^{n} C E P j}{\sum_{j=1}^{n} I C j}=\frac{\overline{C E P}}{\overline{I C}},
$$

where: $\mathrm{CEI}$ - clinical efficiency index; IC - inpatient costs; IC $j$ - inpatient costs for $j$-th patient; $\overline{I C}$ - mean inpatient costs in the period; CEP - Cost Efficiency Points; CEP $j$ - Cost Efficiency Points for $j$-th patient; $\overline{C E P}-$ mean Cost Efficiency Points.

The proposed indicator could be highly useful in analyses of change trends in treatment costs across months or quarterly periods. The efficiency of hospital operations can be compared against a selected reference point to determine changes over time and to objectively evaluate the examined processes. The absolute deviation method was developed and a cause and effect analysis of deviations was carried out to determine which factors contributed most to the observed changes.

Table 1. Hospital efficiency assessment

\begin{tabular}{|c|c|c|c|c|}
\hline CEI & $C E I_{i}<\overline{C E I}-S D$ & $\overline{C E I}-S D<C E I_{i}<\overline{C E I}$ & $\overline{C E I}<C E I_{i}<\overline{C E I}+S D$ & $\overline{C E I}+S D<C E I_{i}$ \\
\hline Very high & & & & $\begin{array}{c}\text { Definitely } \\
\text { efficient }\end{array}$ \\
\hline High & & & Efficient & \\
\hline Low & & Not efficient & & \\
\hline Very low & $\begin{array}{c}\text { Definitely not } \\
\text { efficient }\end{array}$ & & & \\
\hline
\end{tabular}

CEI $i$ - clinical efficiency index for $i$-th month; SD - standard deviation; $\overline{C E I}-$ mean clinical efficiency index for $i$-th month

Source: own elaboration.

\section{Research methods}

The aim of the study is to develop a new measure - the clinical efficiency index (CEI) - which can be used to evaluate the operational efficiency of a hospital based on both, costs and clinical factors. We investigated whether, based on CEI, managers can find the answer to the following questions:

1. Did the observed changes in hospital costs result from changes in patients' health status?

2. If hospital costs were influenced by changes in patients' health status, and by what factors were these changes driven? 
We tested the developed method using data from the Regional Specialist Hospital in Olsztyn, Poland. The hospital provides diagnostics, therapy, care, specialist advice, education, prevention, and health promotion. It is the biggest public hospital in the region financed by the National Health Fund (NFZ). The hospital has 455 beds, more than 130,000 outpatient visits per year and more than 15,000 inpatient admissions per year with occupancy rates of about $80 \%$. Between January and June 2018 there were 3675 patients admitted to the Departments of Cardiology, Laryngology, Ophthalmology, Nephrology, ICU, Gastroenterology, Orthopedics, Surgery, Neurosurgery, Gynecology, Endocrinology, Diabetology and Hematology. We reviewed all of the patients that were admitted to the hospital departments during a six-month period, except newborns $(n=368)$. Some of the patients were excluded from the analysis because of missing data $(\mathrm{n}=338)$. Finally, we included in the analysis 2969 patients.

As presented in Table 2, in the studied period there were 2969 hospitalized patients. The largest number of patients was hospitalized in April (552) and the smallest in February (443). On the studied population the mean length of stay in hospital was 3.83 days. The longest mean LOS was in March (4.01) and the shortest in April (3.71). The mean treatment costs were 3795.91 PLN. The highest mean costs were in May (3862.91) and June (3861.68).

Table 2. Characteristics of hospitalized patients between January and June in 2018

\begin{tabular}{|c|c|c|c|r|r|}
\hline \multirow{2}{*}{ Month } & \multirow{2}{*}{$\begin{array}{c}\text { No. of } \\
\text { patients }[n]\end{array}$} & \multirow{2}{*}{$\begin{array}{c}\text { Hospitalization } \\
{[\text { days] }}\end{array}$} & \multirow{2}{*}{$\begin{array}{c}\text { LOS } \\
\text { [days] }\end{array}$} & \multicolumn{2}{|c|}{ In-patient costs [PLN] } \\
\cline { 5 - 6 } & 493 & 1916 & 3.88 & $3692.82(5196.55)$ & 2094847.51 \\
\hline 2 & 443 & 1634 & 3.68 & $3818.56(25146.54)$ & 2714628.90 \\
\hline 3 & 552 & 2216 & 4.01 & $3725.88(16693.24)$ & 3089403.18 \\
\hline 4 & 509 & 1890 & 3.71 & $3833.21(11905.11)$ & 2917711.98 \\
\hline 5 & 478 & 1825 & 3.82 & $3862.91(6491.54)$ & 2371959.47 \\
\hline 6 & 490 & 1864 & 3.80 & $3861.68(7439.46)$ & 2514857.78 \\
\hline Total & 2969 & 11371 & 3.83 & $3795.91(13834.08)$ & 15743568.3 \\
\hline
\end{tabular}

LOS - length of stay.

Source: own elaboration.

Most of the patients were admitted to hospital within elective hospitalization (1942) and more than $18 \%$ of them were admitted in May (Table 3). About $14 \%$ of the patients were admitted to hospital within emergency hospitalization (464) and almost $13 \%$ were transported by ambulance (383).

In the studied hospital the calculation of inpatient costs involved five steps:

1. Assigning direct costs to patients.

2. The allocation of costs to final, medical and non-medical cost support centers.

3. The allocation of non-medical (transportation, laundry) support costs centers' costs to medical (laboratory, operating room) support and final (wards) cost centers. 
4. Calculation of intermediate products costs (e.g. laboratory tests, diagnosis tests, surgical interventions).

5. Assigning intermediate products and administration costs to final cost centers.

6. Calculation of inpatient costs covered direct costs (drugs, intermediate product costs) and overhead costs (based on the length of stay).

Table 3. Number of hospitalized patients by type of admission between January and June 2018

\begin{tabular}{|c|c|c|c|c|c|c|}
\hline \multirow{3}{*}{ Month } & \multicolumn{7}{|c|}{ Type of admission $[n]$} \\
\cline { 2 - 7 } & $\begin{array}{c}\text { From other } \\
\text { hospital }\end{array}$ & Ambulance & Emergency & Elective & Oncological & Unknown \\
\hline 1 & 0 & 78 & 78 & 321 & 16 & 0 \\
\hline 2 & 2 & 68 & 60 & 296 & 17 & 0 \\
\hline 3 & 67 & 58 & 74 & 345 & 8 & 0 \\
\hline 4 & 31 & 67 & 69 & 341 & 1 & 0 \\
\hline 5 & 14 & 45 & 55 & 352 & 12 & 0 \\
\hline 6 & 14 & 67 & 79 & 287 & 30 & 13 \\
\hline Total & 130 & 383 & 416 & 1942 & 85 & 13 \\
\hline
\end{tabular}

$n$ - number of patients.

Source: own elaboration.

The study involved a three stage approach: (i) multivariable logistic regression analyses were used to determine the predictors of $\mathrm{CO}$ (ii) beta coefficients from the multivariable logistic regression analysis were used to determine cost intensity of treatment described by CEP (iii) assigning CEP to patients (iv) calculating CEI for each patient. To select the outliers we used the interquartile method using the median and the interquartile distance [Cygańska 2016]. To select the high outliers, the 75th percentile $+1.5 *$ interquartile range was used. To identify the low outliers we used the 25 th percentile $-1.5^{*}$ interquartile range. Because the rule 25 th percentile $-1.5^{*}$ interquartile range detected a negative trim-point in further analysis, we considered only the high cost outliers. We considered gender, LOS, and type of admission as the possible factors that may influence the patient being a cost outlier. Multivariable logistic regression analysis were used to determine the predictors of $\mathrm{CO}$. A significance level of 0.05 was adopted as the criterion for entering the factors into the regression model. Statistical analysis was carried out using StatSoft, Inc. (2011) STATISTICA, version 13.3.

\section{Results and discussion}

To calculate the CEI, in the first step the possible factors that may influence the patient being a cost outlier were identified (Table 4). The multivariate logistic regression model confirmed that LOS and type of admission influence a patient's probability of being a cost outlier (CO). 
Table 4. Multivariate logistic regression model to define Clinical Efficiency Points

\begin{tabular}{|l|c|c|c|c|}
\hline \multicolumn{1}{|c|}{ Variables } & $\beta$ - coefficient & OR & IC & $p$-Value \\
\hline LOS & 0.291 & 1.337 & $(1.294-1.382)$ & $<0.001$ \\
\hline Type of admission - oncological & 1.680 & 5.366 & $(2.434-11.831)$ & $<0.001$ \\
\hline Type of admission - urgent & -0.794 & 0.452 & $(0.218-0.940)$ & $<0.001$ \\
\hline Type of admission - ambulance & -1.320 & 0.267 & $(0.121-0.589)$ & $<0.001$ \\
\hline
\end{tabular}

OR - Odds Ratio; IC - Interval Confidence; LOS - length of stay ; CEP - Clinical Efficiency Points; $* p$-value - statistical significance for multivariate logistic regression analysis.

Source: own elaboration.

The probability of being $\mathrm{CO}$ increases more than 5.36 times for patients admitted within oncological admission and more than $33.7 \%$ for each additional day in hospital. For patients admitted within emergency admission or transported to hospital by ambulance the probability of being $\mathrm{CO}$ decreases more than $55 \%$ and $73 \%$, respectively.

In the second stage, beta coefficients were used to calculate CEP for a qualitative description of patient-related parameters, according to the rule presented in Table 5. According to the type of admission, the points presented in Table 5 were assigned for each patient who fulfilled the requirements. For example, to each patient 0.291 point for each day in hospital was assigned.

Table 5. The number of Clinical Efficiency Points assigned to the patient

\begin{tabular}{|c|c|}
\hline Variables & $B$ \\
\hline LOS & $\beta_{1}=\mathbf{0 . 2 9 1}$ for each day in hospital \\
\hline Type of admission - oncology & $\beta_{2}=\mathbf{1 . 6 8 0}$ if present \\
\hline Type of admission - urgent & $B_{3}=\mathbf{- 0 . 7 9 4}$ if present \\
\hline Type of admission - ambulance & $B_{4}=\mathbf{- 1 . 3 2 0}$ if present \\
\hline
\end{tabular}

Source: own elaboration.

The beta coefficients assigned to patients resulting in total and mean CEP within the months are presented in Table 6 . According to the formula 1, CEI rates for each month were determined. The level of efficiency was determined according to the rules presented in Table 1.

The number of CEP by months shows patient health status described by factors influencing costs. The highest number of cost consuming patients in terms of LOS and type of admission was in March. The mean CEP was 1.2413 , and was mainly related to higher than average LOS (4.01) in this month (Table 2). Total costs in March were respectively the highest. The lowest inpatient costs were in January, which can be related to the highest efficiency. However, after taking into account 
Małgorzata Cygańska

Table 6. The Clinical Efficiency Points (CEP) and Clinical Efficiency Index (CEI) by months

\begin{tabular}{|c|c|c|c|c|}
\hline \multirow{2}{*}{ Month } & \multicolumn{2}{|c|}{ CEP } & \multicolumn{2}{|c|}{ CEI } \\
\hline & total & Mean (SD) & rate & evaluation \\
\hline 1 & 465.84 & $0.9298(1.3491)$ & $2.0656(2.6774)$ & Not efficient - \\
\hline 2 & 488.99 & $1.0723(2.7095)$ & $1.9735(2.5726)$ & Not efficient - \\
\hline 3 & 705.04 & $1.2413(3.1249)$ & $2.5456(2.4745)$ & Efficient - \\
\hline 4 & 551.78 & $1.0411(2.8074)$ & $2.1734(2.0034)$ & Not efficient - \\
\hline 5 & 525.18 & $1.0631(1.3806)$ & 4.0975 (35.2143) & Efficient - \\
\hline 6 & 530.08 & $1.0435(1.5890)$ & $2.2035(2.7534)$ & Not efficient - \\
\hline Total & 3266.91 & $0.8811(1.0870)$ & $2.5411(14.6059)$ & \\
\hline
\end{tabular}

Source: own elaboration.

the health status in January, we can presume that lowest costs (mean costs 3692.82, Table 2) were related to good health status of the patient (mean CEP 0.9298, Table 6). When analyzing the CEI, the highest efficiency measured as the relation between patient health status hospitalization costs was in May (4.0975) and the lowest in February (1.9735). As assumed, the causal relationship between resource use and treatment is limited when standard principles performance measure systems are used. In the traditional approach, cost efficiency measures or quality measures are used separately as financial or quality performance measures [Davis et al. 2013; Kludacz 2009; Michalak 2012].

Our study revealed that conclusions drawn from financial analysis differ when covering clinical aspects. The use of CEI helps in analyzing how the operating costs of a hospital changed in the analyzed period, but it also helps in explaining the cause of the observed changes.

Based on the correlations between the hospital costs and the number CEP describing patients' health status, the following groups of patients can be identified:

- patients whose high treatment costs are explained by their health status,

- patients whose low treatment costs are not explained by their health status,

- patients whose low treatment costs are explained by their health status,

- patients whose high treatment costs are not explained by their health status.

The above classification system can be used to identify patients whose high treatment costs are not justified by their health status. High hospital costs can be reduced by identifying the underlying causes. The developed CEI can be successfully implemented especially in the hospitals that use other performance measurement systems, like Balanced Scored.

\section{Conclusion}

The aim of the study was to develop a new measure - the clinical efficiency index which can be used to evaluate the operational efficiency of a hospital based on both, costs and clinical factors The proposed concept supports the hospital performance 
measurement system from the point of view of resource use and healthcare services which are influenced by patient-related parameters measured with the use of CEP. The findings indicated that the choice of the developed approach to analysing hospital performance affects the results in comparison to traditional ones. With multivariate logistic regression analysis we confirmed the influence of patient health status, determined by LOS and type of admission, on hospital costs.

The main contribution of this work is to provide healthcare professionals with a more focused perspective towards incorporating clinical factors into a hospital performance measurement system. Building this framework for CEI is essential not only to report on performance, highlight deficiencies and suggest improvements, but also to stimulate more new ideas and suggestions on monitoring both quality and financial performances. To the best of the author's knowledge, an efficiency index incorporating clinical and financial factors, has not been covered yet. Most of the work on assessing hospital performance has been restricted to various indicators developed separately for finance, health outcomes, distribution, productivity, and patient satisfaction.

We considered only LOS, gender and type of admission as the possible factors that may influence hospital costs. Other variables describing patient health status that may influence hospital costs were not covered in the analysis because of limited data within the hospital information system. In the future, new cost-forming factors can be included in the cost calculation model. Such factors could include hospital complications, rare diseases, non-linear increase in treatment costs of terminally ill patients, ineffective diagnostic procedures where medical tests have to be repeated or more expensive tests have to be carried out to verify previous results and diagnoses, and inter-hospital transfers as part of reference treatment which involve non-standard procedures.

\section{Bibliography}

Chluska J., 2017, Wynik finansowy szpitala - aspekty informacyjne i decyzyjne, Prace Naukowe Uniwersytetu Ekonomicznego we Wrocławiu, (471).

Cohen D.I., Jones P., Littenberg B., Neuhauser D., 1982, Does cost information availability reduce physician test usage? A randomized clinical trial with unexpected findings, Medical Care, 20 (3).

Cygańska M., 2016, The impact factors on the hospital high length of stay outliers, Procedia Economics and Finance, 39, pp. 251-255.

Cygańska M., 2018, Integracja informacji finansowych $i$ klinicznych na potrzeby zarządzania operacyjnego szpitalem, Wydawnictwo Uniwersytetu Warmińsko-Mazurskiego w Olsztynie, Olsztyn.

Davis P., Milne B., Parker K., Hider P., Lay-Yee R., Cumming J., Graham P., 2013, Efficiency, effectiveness, equity (E3). Evaluating hospital performance in three dimensions, Health Policy, 112(1-2), pp. 19-27. 
Ferguson K., Lapsley I., 1989, Resource management in the NHS: The information requirements of hospital doctors, Public Money \& Management, 9(4).

Ford R.C., Bach S.A., Fottler M.D., 1997, Methods of measuring patient satisfaction in health care organizations, Health Care Management Review, 22(2).

Frazier L.M., Brown J.T., Divine G.W., Fleming G.R., Philips N.M., Siegal W.C., Khayrallah M.A., 1991, Can physician education lower the cost of prescription drugs? A prospective, controlled trial, Annals of Internal Medicine, 115(2).

Hafner J.M., Williams S.C., Koss R.G., Tschurtz B.A., Schmaltz S.P., Loeb J.M., 2011, The perceived impact of public reporting hospital performance data: Interviews with hospital staff, International Journal for Quality in Health Care, 23(6), pp. 697-704.

Hass-Symotiuk M. (ed.), 2011, System pomiaru i oceny dokonań szpitala, Wolters Kluwer, Kraków.

Jacobs K., Marcon G., Witt D., 2004, Cost and performance information for doctors: An international comparison, Management Accounting Research, 15(3).

Khalifa M., Khalid P., 2015, Developing strategic health care key performance indicators: A case study on a tertiary care hospital, Procedia Computer Science, 63, pp. 459-466.

Kludacz M., 2009, Płaszczyzny pomiaru i oceny dokonań szpitala w zrównoważonej karcie wyników, Prace Naukowe Uniwersytetu Ekonomicznego we Wrocławiu, 56, pp. 177-185.

Linna M., Häkkinen U., Magnussen J., 2006, Comparing hospital cost efficiency between Norway and Finland. Health Policy, 77(3), pp. 268-278.

Michalak J., 2012, Próba oceny korzyści zastosowania zbilansowanej karty wyników w szpitalach, Acta Universitatis Lodziensis. Folia Oeconomica.

Nita B. (ed.), 2010, Performance Measurement and Management, Publishing House of Wrocław University of Economics.

Nowak E. (ed.), 2012, Pomiar i raportowanie dokonań przedsiębiorstwa, CeDeWu, Warszawa.

Raulinajtys-Grzybek M., Baran W., Macuda M., 2017, Cost accounting in public hospitals in Poland: Usefulness for internal and external purpose, Journal of Health Management, 19(2), pp. 275-291.

Sitzia J., Wood N., 1997, Patient satisfaction: A view of issues and concept, Social Science \& Medicine, 45(12), pp. 1829-1843. 